\title{
Pyridinolysis of Dipropyl Chlorothiophosphate in Acetonitrile
}

\author{
Md. Ehtesham Ul Hoque and Hai Whang Lee* \\ Department of Chemistry, Inha University, Incheon 402-751, Korea. *E-mail: hwlee@inha.ac.kr \\ Received October 31, 2011, Accepted November 10, 2011
}

Key Words : Phosphoryl transfer reaction, Pyridinolysis, Dipropyl chlorothiophosphate, Biphasic concave upward free energy relationship

Continuing the kinetic studies of the pyridinolyses of dimethyl [1: $\left.(\mathrm{MeO})_{2} \mathrm{P}(=\mathrm{S}) \mathrm{Cl}\right],{ }^{1}$ diethyl [2: $\left.(\mathrm{EtO}){ }_{2} \mathrm{P}(=\mathrm{S}) \mathrm{Cl}\right],{ }^{1}$ $\mathrm{Y}$-aryl ethyl $\left[4:(\mathrm{EtO})\left(\mathrm{YC}_{6} \mathrm{H}_{4} \mathrm{O}\right) \mathrm{P}(=\mathrm{S}) \mathrm{Cl}\right],{ }^{2}$ and $\mathrm{Y}$-aryl phenyl [5: $\left.(\mathrm{PhO})\left(\mathrm{YC}_{6} \mathrm{H}_{4} \mathrm{O}\right) \mathrm{P}(=\mathrm{S}) \mathrm{Cl}\right]^{3}$ chlorothiophosphates, the nucleophilic substitution reactions of dipropyl chlorothiophosphate (3) with substituted X-pyridines are investigated kinetically in acetonitrile $(\mathrm{MeCN})$ at $35.0 \pm 0.1{ }^{\circ} \mathrm{C}$ (Scheme 1) to gain further systematic information into the reactivity and mechanism depending on the variation of the two ligands, $\mathrm{R}_{1} \mathrm{O}$ and $\mathrm{R}_{2} \mathrm{O}$, where $\mathrm{R}_{1}$ and $\mathrm{R}_{2}$ are alkyl and/or phenyl (aryl). The numbering of the substrates of 1-5 follows the sequence of the size of the two ligands, $\mathrm{R}_{1} \mathrm{O}$ and $\mathrm{R}_{2} \mathrm{O}$.

\section{Results and Discussion}

The reactions were carried out under pseudo-first-order conditions with a large excess of pyridine. The observed pseudo-first-order rate constants $\left(k_{\text {obsd }}\right)$ for all reactions obeyed eq. (1) with negligible $k_{0}(\approx 0)$ in $\mathrm{MeCN}$. The second-order rate constants were determined with at least five pyridine concentrations. The linear plots of eq. (1) suggest a lack of any base-catalysis or side reactions, and the overall reaction is described by Scheme 1 .

$$
k_{\mathrm{obsd}}=k_{0}+k_{2}\left[\mathrm{XC}_{5} \mathrm{H}_{4} \mathrm{~N}\right]
$$

The second-order rate constants $\left[k_{2}\left(\mathrm{M}^{-1} \mathrm{~s}^{-1}\right)\right]$ are summarized in Table 1 . The Brönsted $\beta_{\mathrm{X}}$ value was calculated by

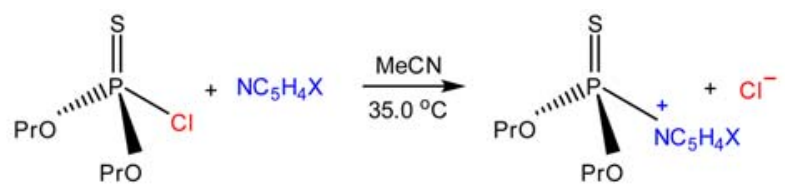

$\mathrm{X}=4-\mathrm{MeO}, 4-\mathrm{Me}, 3-\mathrm{Me}, \mathrm{H}, 3-\mathrm{Ph}, 3-\mathrm{MeO}, 3-\mathrm{Cl}, 3-\mathrm{Ac}, 4-\mathrm{Ac}, 3-\mathrm{CN}, 4-\mathrm{CN}$

Scheme 1. The reactions of dipropyl chlorothiophosphate (3) with substituted X-pyridines in $\mathrm{MeCN}$ at $35.0{ }^{\circ} \mathrm{C}$. correlating $\log k_{2}(\mathrm{MeCN})$ with $\mathrm{p} K_{\mathrm{a}}\left(\mathrm{H}_{2} \mathrm{O}\right),{ }^{4}$ which was justified theoretically and experimentally. ${ }^{5}$ The substituent effects of the nucleophiles upon the pyridinolysis rates correlate with those for a typical nucleophilic substitution reaction where the stronger nucleophile leads to a faster rate. However, both the Hammett (log $k_{2} v s \quad \sigma_{\mathrm{x}}$; Fig. 1) and Brönsted [log $k_{2} v s \quad \mathrm{p} K_{\mathrm{a}}(\mathrm{X})$; Fig. 2] plots are biphasic concave upwards with a break point at $\mathrm{X}=3-\mathrm{Ph}$. The magnitudes of $\rho_{\mathrm{X}}(=-5.27)$ and $\beta_{\mathrm{X}}(=1.08)$ values with the strongly basic pyridines (X = 4-MeO, 4-Me, 3-Me, H, 3-Ph) are much greater than those $\left(\rho_{\mathrm{X}}=-1.80\right.$ and $\left.\beta_{\mathrm{X}}=0.31\right)$ with the weakly basic pyridines ( $\mathrm{X}=3-\mathrm{Ph}, 3-\mathrm{MeO}, 3-\mathrm{Cl}, 3-\mathrm{Ac}$, 4Ac, 3-CN, 4-CN).

The second-order rate constants $\left(k_{2}\right)$ with unsubstituted pyridine $\left(\mathrm{C}_{5} \mathrm{H}_{5} \mathrm{~N}\right)$ at $35.0{ }^{\circ} \mathrm{C}$, natural bond order $(\mathrm{NBO})$ charges at the reaction center $\mathrm{P}$ atom in the substrate in the gas phase $[\mathrm{B} 3 \mathrm{LYP} / 6-311+\mathrm{G}(\mathrm{d}, \mathrm{p})$ level of theory $]{ }^{6}$ summations

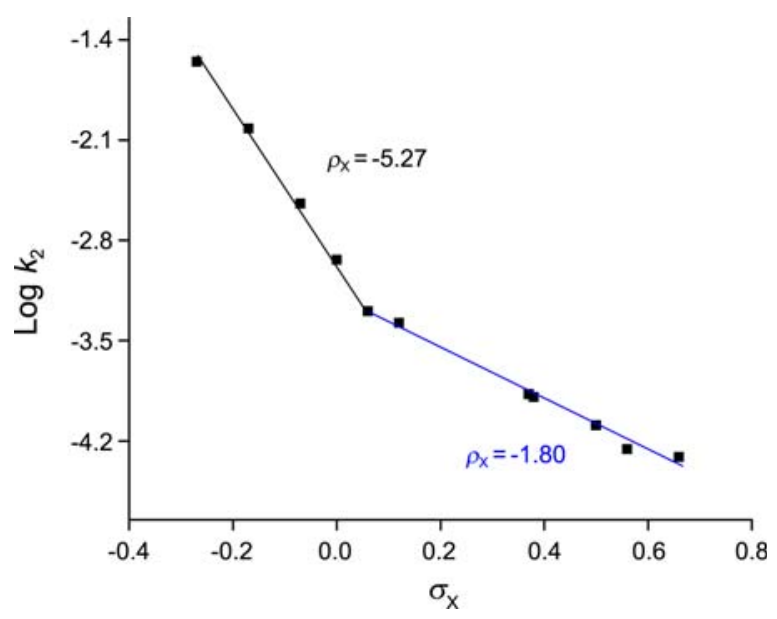

Figure 1. The Hammett plot $\left(\log k_{2} v s \sigma_{\mathrm{X}}\right)$ of the reactions of dipropyl chlorothiophosphate (3) with X-pyridines in $\mathrm{MeCN}$ at $35.0^{\circ} \mathrm{C}$. The values of $\rho_{\mathrm{X}}$ are $-5.27 \pm 0.04(\mathrm{r}=0.999)$ with $\mathrm{X}=(4-$ $\mathrm{MeO}$, 4-Me, 3-Me, H, 3-Ph) and $-1.80 \pm 0.04(\mathrm{r}=0.995)$ with $\mathrm{X}=$ (3-Ph, 3-MeO, 3-Cl, 3-Ac, 4-Ac, 3-CN, 4-CN).

Table 1. Second-Order Rate Constants $\left(k_{2} \times 10^{4} / \mathrm{M}^{-1} \mathrm{~s}^{-1}\right)$ of the Reactions of Dipropyl Chlorothiophosphate (3) with $\mathrm{XC}_{5} \mathrm{H}_{4} \mathrm{~N}$ in $\mathrm{MeCN}$ at $35.0^{\circ} \mathrm{C}$

\begin{tabular}{ccccccccccccccc}
\hline $\mathrm{X}$ & $4-\mathrm{MeO}$ & $4-\mathrm{Me}$ & $3-\mathrm{Me}$ & $\mathrm{H}$ & $3-\mathrm{Ph}$ & 3-MeO & 3-Cl & 3-Ac & 4-Ac & 3-CN & 4-CN \\
\hline$k_{2}$ & 280 & 95.6 & 28.6 & 11.6 & 5.08 & 4.22 & 1.34 & 1.28 & 0.811 & 0.555 & 0.489 \\
$\times 10^{4}$ & \pm 1 & \pm 0.2 & \pm 0.1 & \pm 0.1 & \pm 0.02 & \pm 0.02 & \pm 0.01 & \pm 0.01 & \pm 0.004 & \pm 0.002 & \pm 0.002 \\
\hline
\end{tabular}




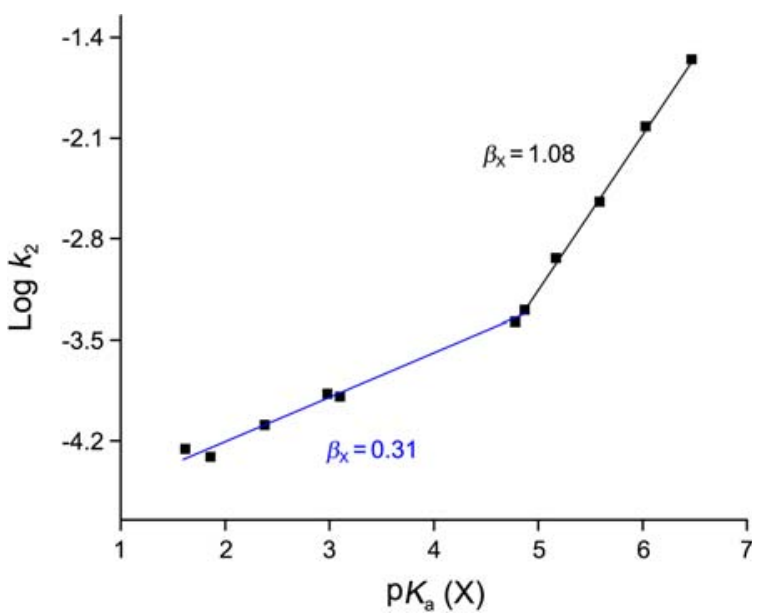

Figure 2. The Brönsted plot $\left[\log k_{2} v s \mathrm{p} K_{\mathrm{a}}(\mathrm{X})\right]$ of the reactions of dipropyl chlorothiophosphate (3) with X-pyridines in $\mathrm{MeCN}$ at $35.0{ }^{\circ} \mathrm{C}$. The values of $\beta_{\mathrm{X}}$ are $1.08 \pm 0.03(\mathrm{r}=0.999)$ with $\mathrm{X}=(4-$ $\mathrm{MeO}, 4-\mathrm{Me}, 3-\mathrm{Me}, \mathrm{H}, 3-\mathrm{Ph})$ and $0.31 \pm 0.05(\mathrm{r}=0.994)$ with $\mathrm{X}=$ (3-Ph, 3-MeO, 3-Cl, 3-Ac, 4-Ac, 3-CN, 4-CN).

of the Taft's steric constants $\left[\Sigma E_{\mathrm{S}}=E_{\mathrm{S}}\left(\mathrm{R}_{1}\right)+E_{\mathrm{S}}\left(\mathrm{R}_{2}\right)\right]$ of the two ligands, ${ }^{7}$ Brönsted coefficients $\left(\beta_{\mathrm{X}}\right)$, cross-interaction constants (CICs; $\left.\rho_{\mathrm{XY}}\right),{ }^{8}$ and variation trends of the free energy relationships with $\mathrm{X}$ for the pyridinolyses of five $\left(\mathrm{R}_{1} \mathrm{O}\right)\left(\mathrm{R}_{2} \mathrm{O}\right) \mathrm{P}(=\mathrm{S}) \mathrm{Cl}$-type chlorothiophosphates in $\mathrm{MeCN}$ are summarized in Table 2. When the magnitude of the positive charge of the reaction center $\mathrm{P}$ atom (i.e., electrophilicity) in the substrate plays an important role to determine the pyridinolysis rate, the sequence of the pyridinolysis rate should be $\mathbf{3}>\mathbf{2}>\mathbf{1} \approx \mathbf{4}>\mathbf{5}$. On the other hand, when the steric effects of the two ligands, $\mathrm{R}_{1} \mathrm{O}$ and $\mathrm{R}_{2} \mathrm{O}$, play an important role, the sequence of the rate should be $\mathbf{1}>\mathbf{2}>\mathbf{3}>\mathbf{4}>\mathbf{5}$. However, the observed sequence of the pyridinolyses rates of $\mathbf{1}>\mathbf{2} \geq \mathbf{3}>\mathbf{5}>\mathbf{4}$ [the relative rate ratio of 11.2(1):8.7(2):8.5(3):2.4(5):1(4)] does not show systematic consistency with the NBO charge at $\mathrm{P}$ atom or $\Sigma E_{\mathrm{S}}$ of the two ligands. These results indicate that the pyridinolysis rates of $\left(\mathrm{R}_{1} \mathrm{O}\right)\left(\mathrm{R}_{2} \mathrm{O}\right) \mathrm{P}(=\mathrm{S}) \mathrm{Cl}$-type substrates in $\mathrm{MeCN}$ are not dependent upon one dominant factor but on many factors. As observed in the pyridinolyses of chlorothiophosphates, the pyridinolysis rates of phosphinic chlorides
$\left[\mathrm{R}_{1} \mathrm{R}_{2} \mathrm{P}(=\mathrm{O})\right.$ Cl-type $],{ }^{9}$ chlorophosphates $\left[\left(\mathrm{R}_{1} \mathrm{O}\right)\left(\mathrm{R}_{2} \mathrm{O}\right) \mathrm{P}(=\mathrm{O}) \mathrm{Cl}\right.$ type $],{ }^{1,10}$ thiophosphinic chlorides $\left[\mathrm{R}_{1} \mathrm{R}_{2} \mathrm{P}(=\mathrm{S}) \mathrm{Cl}\right.$-type ${ }^{9 \mathrm{a}, \mathrm{b}, 11}$ and phosphonochloridothioates $\left[\mathrm{R}_{1}\left(\mathrm{R}_{2} \mathrm{O}\right) \mathrm{P}(=\mathrm{S}) \mathrm{Cl} \text {-type }\right]^{12}$ are not also dependent upon one predominant factor.

On the contrary, the anilinolysis rates of the chlorothiophsphates ${ }^{13}$ are predominantly dependent upon the steric effects over the inductive effects of the two ligands. The greater the size of the two ligands, $\mathrm{PhO}, \mathrm{PhO}(\mathbf{5})>$ $\mathrm{EtO}, \mathrm{PhO}(4)>\mathrm{PrO}, \mathrm{PrO}(3)>\mathrm{EtO}, \mathrm{EtO}(2)>\mathrm{MeO}, \mathrm{MeO}(\mathbf{1})$, the anilinolysis rate becomes slower. The second-order rate constants for the reactions of five chlorothiophosphates with $\mathrm{C}_{6} \mathrm{H}_{5} \mathrm{NH}_{2}$ in $\mathrm{MeCN}$ at $55.0{ }^{\circ} \mathrm{C}$ gave the relative rate ratio of $9.9(\mathbf{1})^{13 \mathrm{a}}: 5.1(\mathbf{2})^{13 \mathrm{a} a}: 3.0(\mathbf{3})^{13 \mathrm{~b}}: 2.8(\mathbf{4})^{13 \mathrm{c}}: 1(\mathbf{5}) .^{13 \mathrm{~d}}$ The anilinolysis rates of phosphinic chlorides, ${ }^{14}$ chlorophosphates, ${ }^{13 a, c, 15}$ thiophosphinic chlorides, ${ }^{16}$ phosphinates $\left[\mathrm{R}_{1} \mathrm{R}_{2} \mathrm{P}(=\mathrm{O})(\mathrm{OPhZ})\right.$ type $],{ }^{17}$ and phosphonochloridothioates ${ }^{18}$ are also qualitatively (or sometimes semi-quantitatively) dependent upon the steric effects of the two ligands..$^{19}$ The sensitivity to the steric effects of the two ligands on the anilinolysis rates of phosphinic (and thiophosphinic) chlorides is greater than that of chlorophosphates (and chlorothiophosphates), and that of $\mathrm{P}=\mathrm{O}$ system is greater than that of $\mathrm{P}=\mathrm{S}$ system. It seems that the intervening oxygen atom between the reaction center $\mathrm{P}$ atom and $\mathrm{R}_{\mathrm{i}}$ in chlorophosphates reduces the sensitivity to the steric effects of the two ligands on the anilinolysis rates. In other words, the ligand, $\mathrm{R}_{\mathrm{i}}$, is directly bonded to $\mathrm{P}$ atom in (thio)phosphinic chloride, while the $\mathrm{R}_{\mathrm{i}}$ group is bonded to the intervening oxygen atom which is bonded to $\mathrm{P}$ atom in chloro(thio)phosphate, and as a result, the available space for the attacking aniline in chloro(thio)phosphate is greater than that in (thio)phosphinic chloride.

As seen in Table 2, the $\beta_{\mathrm{X}}$ values of $\mathbf{1}, \mathbf{2}$, and $\mathbf{3}$ are similar: $\beta_{\mathrm{X}}=1.0-1.1$ with the strongly basic pyridines and $\beta_{\mathrm{X}}=0.2-$ 0.3 with the weakly basic pyridines, strongly suggesting the same reaction mechanisms of the pyridinolyses of 1,2 , and 3. The $\beta_{\mathrm{X}}(\approx 2.3)$ value of $\mathbf{4}$ with the strongly basic pyridines is the greatest one among all over the pyridinolyses of the $\mathrm{P}=\mathrm{O}$ and $\mathrm{P}=\mathrm{S}$ systems studied by this lab. ${ }^{2}$ The $\beta_{\mathrm{X}}(=1.4-$ 1.5) values of 5 with the strongly basic pyridines are relatively great. ${ }^{3}$ The $\beta_{\mathrm{X}}$ values of $\mathbf{4}$ and $\mathbf{5}$ with the weakly basic pyridines are somewhat greater than those of $\mathbf{1}, \mathbf{2}$, and 3. The Hammett plots of $\mathbf{4}$ for the variation of substituent $Y$

Table 2. Summary of the Second-Order Rate Constants $\left(k_{2}\right.$ with $\mathrm{C}_{5} \mathrm{H}_{5} \mathrm{~N}$ at $\left.35.0{ }^{\circ} \mathrm{C}\right)$, NBO Charges at the Reaction Center P Atom, Summations of the Taft's Steric Constants $\left(\Sigma E_{\mathrm{S}}\right)$ of the Two Ligands, Brönsted Coefficients $\left(\beta_{\mathrm{X}}\right)$, CICs $\left(\rho_{\mathrm{XY}}\right)$, and Variation Trends of Free Energy Relationships with X for the Pyridinolyses of 1-5 in MeCN

\begin{tabular}{ccccccc}
\hline Substrate & $k_{2} \times 10^{3 a}$ & Charge at $\mathrm{P}$ & $-\Sigma E_{\mathrm{S}}{ }^{d}$ & $\beta_{\mathrm{X}}$ & $\rho_{\mathrm{XY}}$ & Trend \\
\hline $\left.\mathbf{1 :}(\mathrm{MeO})_{2} \mathrm{P}=\mathrm{S}\right) \mathrm{Cl}$ & $1.54^{b}$ & 1.687 & 0 & $1.09 / 0.20^{e}$ & - & $\mathrm{V}^{g}$ \\
$\mathbf{2 :}(\mathrm{EtO})_{2} \mathrm{P}(=\mathrm{S}) \mathrm{Cl}$ & $1.19^{b}$ & 1.701 & 0.14 & $1.02 / 0.29^{e}$ & - & $\mathrm{V}$ \\
3: $(\mathrm{PrO})_{2} \mathrm{P}(=\mathrm{S}) \mathrm{Cl}$ & 1.16 & 1.723 & 0.72 & $1.08 / 0.31^{e}$ & $\mathrm{~V}$ \\
4: $(\mathrm{EtO})\left(\mathrm{YC} \mathrm{H}_{4} \mathrm{O}\right) \mathrm{P}(=\mathrm{S}) \mathrm{Cl}$ & $0.137^{c}$ & $1.687^{c}$ & $2.55^{c}$ & $2.31-2.33 / 0.45-0.47^{e}$ & $0 / 0 / 0 / 0^{f}$ & $\mathrm{~V}$ \\
$\mathbf{5 :}(\mathrm{PhO})\left(\mathrm{YC}_{6} \mathrm{H}_{4} \mathrm{O}\right) \mathrm{P}(=\mathrm{S}) \mathrm{Cl}$ & $0.333^{c}$ & $1.661^{c}$ & $4.96^{c}$ & $1.36-1.50 / 0.23-0.48^{e}$ & $2.42 / 5.14 /-1.02 /-0.04^{f}$ & $\mathrm{~V}$ \\
\hline
\end{tabular}

${ }^{a}$ Second-order rate constant with unsubstituted pyridine $(\mathrm{X}=\mathrm{H})$ at $35.0^{\circ} \mathrm{C} .{ }^{b}$ Extrapolated value in the Arrhenius plot. ${ }^{c}$ The value with $\mathrm{Y}=\mathrm{H} .{ }^{d}$ Note that the value of $\Sigma E_{\mathrm{S}}$ is not ' $E_{\mathrm{S}}\left(\mathrm{R}_{1} \mathrm{O}\right)+E_{\mathrm{S}}\left(\mathrm{R}_{2} \mathrm{O}\right)$ ' but ' $E_{\mathrm{S}}\left(\mathrm{R}_{1}\right)+E_{\mathrm{S}}\left(\mathrm{R}_{2}\right)$ ' because of a lack of data of $E_{\mathrm{S}}\left(\mathrm{R}_{\mathrm{i}} \mathrm{O}\right)$. ${ }^{e}$ Strongly basic/weakly basic pyridines. ${ }^{f}$ Stronger nucleophiles and weaker electrophiles/weaker nucleophiles and weaker electrophiles/stronger nucleophiles and stronger electrophiles/weaker nucleophiles and stronger electrophiles. ${ }^{g}$ The symbol of $\mathrm{V}$ indicates biphasic concave upward free energy correlation with a break point for the variation of $\mathrm{X}$ in the nucleophiles. 
in the substrate are biphasic concave upwards with a break (minimum) point at $\mathrm{Y}=\mathrm{H}$ while those of $\mathbf{5}$ are concave downwards with a break point at $\mathrm{Y}=\mathrm{H}$. Thus, the four values of CICs, $\rho_{\mathrm{XY}}$, were obtained for both 4 and 5 . In 4, the CICs, $\rho_{\mathrm{XY}}$ are all null in spite of the biphasic free energy correlations for both substituent $\mathrm{X}$ and $\mathrm{Y}$ variations, since the $\rho_{\mathrm{X}}$ values with both the strongly and weakly basic pyridines are almost constant. This reaction is the only one, having all $\rho_{\mathrm{XY}}=0$ with four blocks until now: stronger nucleophiles and weaker electrophiles, weaker nucleophiles and weaker electrophiles, stronger nucleophiles and stronger electrophiles, and weaker nucleophiles and stronger electrophiles. Herein, the null of $\rho_{\mathrm{XY}}$ value implies that the distance between $\mathrm{X}$ and $\mathrm{Y}$ does not vary from the intermediate to the second transition state (TS), in which the reaction proceeds through a stepwise mechanism with a rate-limiting leaving group expulsion from the intermediate. A frontside attack TSf (Scheme 2) was proposed with the strongly basic pyridines based on the considerably great magnitudes of $\beta_{\mathrm{X}}$ value and a backside attack involving in-line-type TSb (Scheme 2) was proposed with the weakly basic pyridines based on the relatively small magnitudes of $\beta_{\mathrm{X}}$. In $\mathbf{5}$, a stepwise process was proposed involving a rate-limiting step change from bond breaking with the weaker electrophiles based on the large positive $\rho_{\mathrm{XY}}$ value to bond formation with the stronger eletrophiles based on the negative $\rho_{\mathrm{XY}}$ value. The nonlinear free energy correlations of biphasic concave upward plots with $\mathrm{X}$ in the nucleophiles were rationalized by a change in the attacking direction of the nucleophile from a backside with less basic pyridines to a frontside attack with more basic pyridines.

In the present work, the free energy correlations for substituent $\mathrm{X}$ variations in the pyridines are biphasic concave upwards. The biphasic concave upward free energy relationships are interpreted as a change of the nucleophilic attacking direction from a frontside attack TSf with the strongly basic pyridines based on the considerably great magnitudes of $\beta_{\mathrm{X}}$ value to a backside attack involving in-line-type TSb with the weakly basic pyridines based on the relatively small magnitudes of $\beta_{\mathrm{X}}$ in a concerted process, the same mechanism as in $\mathbf{1}$ and $\mathbf{2}$.

In general, the nonlinear free energy correlation of a concave upward plot is diagnostic of a change in the reaction mechanism, such as parallel reactions where the reaction path is changed depending on the substituents, while nonlinear free energy correlation of the biphasic concave downward plot is diagnostic of a rate-limiting step change from

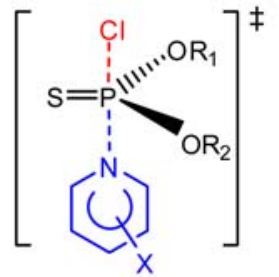

$\mathrm{TSb}$

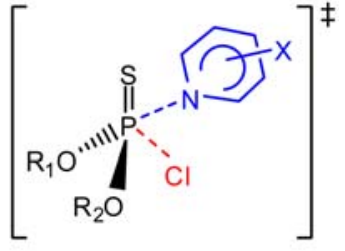

TSf
Scheme 2. Backside attack TSb and frontside attack TSf. bond breaking with less basic nucleophiles to bond formation with more basic nucleophiles. ${ }^{20}$ It is the suggestion of the authors that the concave upward Hammett and Brönsted plots can also be diagnostic of a change in the attacking direction of the nucleophile depending on the substituents from backside to frontside. It is worthy of note that a frontside attack TSf yields greater magnitudes of $\rho_{\mathrm{X}}$ and $\beta_{\mathrm{X}}$ values compared to a backside attack. ${ }^{21}$

In summary, the kinetic studies on the pyridinolysis of dipropyl chlorothiophosphate have been carried out in $\mathrm{MeCN}$ at $35.0{ }^{\circ} \mathrm{C}$. The free energy correlations are biphasic concave upwards with a break point at $\mathrm{X}=3-\mathrm{Ph}$. A concerted $\mathrm{S}_{\mathrm{N}} 2$ mechanism is proposed with a change of the attacking direction of the X-pyridine from a frontside attack with the strongly basic pyridines to a backside attack with the weakly basic pyridines.

\section{Experimental Section}

Materials. Dipropyl chlorothiophosphate, GR grade pyridines and HPLC grade acetonitrile (water content is less than $0.005 \%$ ) were used for kinetic studies without further purification.

Kinetic Procedure. Rates were measured conductometrically at $35.0{ }^{\circ} \mathrm{C}$. The conductivity bridge used in this work was a self-made computer automated A/D converter conductivity bridge. The pseudo-first-order rate constants, $k_{\text {obsd, }}$, were measured by curve fitting analysis in origin program with a large excess of pyridines, [substrate] $=1 \times 10^{-3}$ $\mathrm{M}$ and $\left[\mathrm{XC}_{5} \mathrm{H}_{4} \mathrm{~N}\right]=(0.1-0.3) \mathrm{M}$. Second-order rate constants, $k_{2}$, were obtained from the slope of a plot of $k_{\text {obsd }} v s$ [X-pyridine] at least with five concentrations of pyridine. The pseudo-first-order rate constant values $\left(k_{\mathrm{obsd}}\right)$ were the average of three runs that were reproducible within $\pm 3 \%$.

Product Analysis. Dipropyl chlorothiophosphate was reacted with excess pyridine, for more than 15 half-lives at $35.0{ }^{\circ} \mathrm{C}$ in $\mathrm{MeCN}$. Acetonitrile was removed under reduced pressure. The product was isolated by adding ether and insoluble fraction was collected. The product was purified to remove excess pyridine by washing several times with ether. Analytical and spectroscopic data of the product gave the following results:

$\left[(\mathbf{P r O})_{2} \mathbf{P}(=\mathbf{S}) \mathbf{N C}_{5} \mathbf{H}_{5}\right]^{+} \mathbf{C l}^{-}$. Colorless liquid; ${ }^{1} \mathrm{H} \mathrm{NMR}$ (400 MHz, $\left.\mathrm{CDCl}_{3}\right) \delta 0.84-0.97\left(6 \mathrm{H}, \mathrm{m}, 2 \mathrm{CH}_{3}, \mathrm{Pr}\right), 1.60-1.71$ (4H, m, 2 $\left.\mathrm{CH}_{2}, \mathrm{Pr}\right), 4.03-4.12$ (4H, m, $\left.2 \mathrm{CH}_{2}, \mathrm{Pr}\right), 8.02(2 \mathrm{H}, \mathrm{t}$, $J=7.6 \mathrm{~Hz}$, pyridinium $), 8.50(1 \mathrm{H}, \mathrm{t}, J=8.0 \mathrm{~Hz}$, pyridinium $)$, $8.87\left(2 \mathrm{H}, \mathrm{d}, J=9.6 \mathrm{~Hz}\right.$, pyridinium); ${ }^{13} \mathrm{C} \mathrm{NMR}(100 \mathrm{MHz}$, $\left.\mathrm{CDCl}_{3}\right) \delta 9.88\left(\mathrm{CH}_{3}, \mathrm{Pr}\right), 23.13\left(\mathrm{CH}_{2}, \mathrm{Pr}\right), 70.75\left(\mathrm{CH}_{2}, \mathrm{Pr}\right)$, 127.22, 128.42, 141.05, $145.81(\mathrm{C}=\mathrm{C}$, pyridinium $) ;{ }^{31} \mathrm{P}$ NMR $\left(162 \mathrm{MHz}, \mathrm{CDCl}_{3}\right) \delta 58.30(\mathrm{~s}, 1 \mathrm{P}, \mathrm{P}=\mathrm{S}) ; \mathrm{m} / z 295\left(\mathrm{M}^{+}\right)$.

Acknowledgments. This work was supported by Inha University Research Grant.

\section{References and Notes}

1. Dey, N. K.; Hoque, M. E. U.; Kim, C. K.; Lee, H. W. J. Phys. Org. 
Chem. 2010, 23, 1022.

2. Adhikary, K. K.; Lee, H. W. Bull. Korean Chem. Soc. 2011, 32, 3947.

3. Hoque, M. E. U.; Dey, S.; Kim, C. K.; Lee, H. W. Bull. Korean Chem. Soc. 2011, 32, 1138.

4. (a) Fischer, A.; Galloway, W. J.; Vaughan, J. J. Chem. Soc. 1964, 3591. (b) Dean, J. A. Handbook of Organic Chemistry; McGrawHill: New York, 1987; Chapter 8. (c) Castro, E. A.; Freudenberg, M. J. Org. Chem. 1980, 45, 906.

5. (a) Lee, I.; Kim, C. K.; Han, I. S.; Lee, H. W.; Kim, W. K.; Kim, Y. B. J. Phys. Chem. B 1999, 103, 7302. (b) Coetzee, J. F. Prog. Phys. Org. Chem. 1967, 4, 45.

6. Hehre, W. J.; Random, L.; Schleyer, P. V. R.; Pople, J. A. Ab Initio Molecular Orbital Theory; Wiley: New York, 1986; Chapter 4.

7. (a) Taft, R. W. Steric Effect in Organic Chemistry, ed. Newman, M. S.; Wiley: New York, 1956; Chapter 3. (b) Exner, O. Correlation Analysis in Chemistry: Recent Advances; Chapman, N. B.; Shorter, J. Eds; Plenum Press: New York, 1978; p 439.

8. In general, the negative sign of $\rho_{\mathrm{XY}}$ implies that the reaction proceeds through a concerted mechanism, while a stepwise mechanism with a rate-limiting leaving group expulsion from the intermediate with the positive sign of $\rho_{\mathrm{XY}}$, and the magnitude of $\rho_{\mathrm{XY}}$ value is inversely proportional to the distance between $\mathrm{X}$ and Y through the reaction center: (a) Lee, I. Chem. Soc. Rev. 1990, 19, 317. (b) Lee, I. Adv. Phys. Org. Chem. 1992, 27, 57. (c) Lee, I.; Lee, H. W. Collect. Czech. Chem. Commun. 1999, 64, 1529.

9. (a) Hoque, M. E. U.; Dey, N. K.; Guha, A. K.; Kim, C. K.; Lee, B. S.; Lee, H. W. Bull. Korean Chem. Soc. 2007, 28, 1797. (b) Dey, N. K.; Adhikary, K. K.; Kim, C. K.; Lee, H. W. Bull. Korean Chem. Soc. 2010, 31, 3856. (c) Dey, N. K.; Kim, C. K.; Lee, H. W. Bull. Korean Chem. Soc. 2011, 32, 709. (d) Adhikary, K. K.; Lee, H. W. Bull. Korean Chem. Soc. 2011, 32, 1945. (e) Hoque, M. E. U.; Lee, H. W. Bull. Korean Chem. Soc. 2011, 32, 2109.

10. (a) Guha, A. K.; Lee, H. W.; Lee, I. J. Org. Chem. 2000, 65, 12. (b) Hoque, M. E. U.; Lee, H. W. Bull. Korean Chem. Soc. 2011, 32,3505 .

11. (a) Hoque, M. E. U.; Lee, H. W. Bull. Korean Chem. Soc. 2011, 32, 2805. (b) Hoque, M. E. U.; Lee, H. W. Bull. Korean Chem. Soc. 2011, 32, 4387.

12. (a) Lumbiny, B. J.; Adhikary, K. K.; Lee, B. S.; Lee, H. W. Bull. Korean Chem. Soc. 2008, 29, 1769. (b) Guha, A. K.; Hoque, M. E. U.; Lee, H. W. Bull. Korean Chem. Soc. 2011, 32, 1375.

13. (a) Dey, N. K.; Hoque, M. E. U.; Kim, C. K.; Lee, B. S.; Lee, H. W. J. Phys. Org. Chem. 2008, 21, 544. (b) Hoque, M. E. U.; Lee, H. W. Bull. Korean Chem. Soc. 2011, 32, 4403. (c) Hoque, M. E. U.; Dey, N. K.; Kim, C. K.; Lee, B. S.; Lee, H. W. Org. Biomol. Chem. 2007, 5, 3944. (d) Hoque, M. E. U.; Dey, S.; Guha, A. K.; Kim, C. K.; Lee, B. S.; Lee, H. W. J. Org. Chem. 2007, 72, 5493.
14. (a) Hoque, M. E. U.; Lee, H. W. Bull. Korean Chem. Soc. 2007, 28, 936. (b) Dey, N. K.; Hoque, M. E. U.; Kim, C. K.; Lee, B. S.; Lee, H. W. J. Phys. Org. Chem. 2009, 22, 425. (c) Dey, N. K. Lee, H. W. Bull. Korean Chem. Soc. 2010, 31, 1403. (d) Hoque, M. E. U.; Lee, H. W. Bull. Korean Chem. Soc. 2011, 32, 1997.

15. (a) Guha, A. K.; Lee, H. W.; Lee, I. J. Chem. Soc., Perkin Trans. 2 1999, 765. (b) Lee, H. W.; Guha, A. K.; Lee, I. Int. J. Chem. Kinet. 2002, 34, 632. (c) Barai, H. R.; Lee, H. W. Bull. Korean Chem. Soc. 2011, 32, 1939. (d) Hoque, M. E. U.; Lee, H. W. Bull. Korean Chem. Soc. 2011, 32, 3245. (e) Barai, H. R.; Lee, H. W. Bull. Korean Chem. Soc. 2011, 32, 3783.

16. (a) Dey, N. K.; Han, I. S.; Lee, H. W. Bull. Korean Chem. Soc. 2007, 28, 2003. (b) Dey, N. K.; Kim, C. K.; Lee, H. W. Bull. Korean Chem. Soc. 2009, 30, 975. (c) Hoque, M. E. U.; Lee, H. W. Bull. Korean Chem. Soc. 2011, 32, 2306. (d) Hoque, M. E. U.; Lee, H. W. Bull. Korean Chem. Soc. 2011, 32, 3880.

17. Dey, N. K.; Kim, C. K.; Lee, H. W. Org. Biomol. Chem. 2011, 9 , 717.

18. (a) Hoque, M. E. U.; Guha, A. K.; Kim, C. K.; Lee, B. S.; Lee, H. W. Org. Biomol. Chem. 2009, 7, 2919. (b) Adhikary, K. K.; Lumbiny, B. J.; Dey, S.; Lee, H. W. Bull. Korean Chem. Soc. 2011, 32, 2628.

19. Some ligands (e.g., cyclo-hexyl, $i$-propyl, $i$-propoxy) yield exceptionally slow rates to be rationalized by the conventional stereoelectronic effect.

20. (a) Williams, A. Free Energy Relationships in Organic and Bioorganic Chemistry; RSC: Cambridge, UK, 2003; Chapter 7. (b) Ruff, A.; Csizmadia, I. G. Organic Reactions Equilibria, Kinetics and Mechanism; Elsevier: Amsterdam, Netherlands, 1994; Chapter 7. (c) Oh, H. K.; Lee, J. M.; Lee, H. W.; Lee, I. Int. J. Chem. Kinet. 2004, 36, 434. (d) Oh, H. K.; Park, J. E.; Lee, H. W. Bull. Korean Chem. Soc. 2004, 25, 1041. (e) Oh, H. K.; Ku, M. H.; Lee, H. W.; Lee, I. J. Org. Chem. 2002, 67, 8995. (f) Castro, E. A.; Angel, M.; Campodonico, P.; Santos, J. G. J. Org. Chem. 2002, 67, 8911. (g) Castro, E. A.; Pavez, P.; Santos, J. G. J. Org. Chem. 2002, 67, 4494. (h) Oh, H. K.; Ku, M. H.; Lee, H. W.; Lee, I. J. Org. Chem. 2002, 67, 3874. (i) Castro, E. A.; Pavez, P.; Santos, J. G. J. Org. Chem. 2002, 67, 3129. (j) Castro, E. A.; Pavez, P.; Arellano, D.; Santos, J. G. J. Org. Chem. 2001, 66, 6571. (k) Spillane, W. J.; McGrath, P.; Brack, C.; O’Byrne, A. B. J. Org. Chem. 2001, 66, 6313. (1) Koh, H. J.; Han, K. L.; Lee, H. W.; Lee, I. J. Org. Chem. 2000, 65, 4706. (m) Humeres, E.; Debacher, N. A.; Sierra, M. M. D.; Franco J. D.; Shutz, A. J. Org. Chem. 1998, 63, 1598. (n) Baynham, A. S.; Hibbert, F.; Malana, M. A. J. Chem. Soc., Perkin Trans 2 1993, 1711.

21. Adhikary, K. K.; Lee, H. W.; Lee, I. Bull. Korean Chem. Soc. 2003, 24, 1135. 